\title{
Front Matter: Volume 11629
}

, "Front Matter: Volume 11629," Proc. SPIE 11629, Optical Techniques in Neurosurgery, Neurophotonics, and Optogenetics, 1162901 (23 April 2021); doi: $10.1117 / 12.2596819$

SPIE. Event: SPIE BiOS, 2021, Online Only 


\title{
PROGRESS IN BIOMEDICAL OPTICS AND IMAGING
}

\section{Optical Techniques in Neurosurgery, Neurophotonics, and Optogenetics}

\author{
V. X. D. Yang \\ Q. M. Luo \\ S. K. Mohanty \\ J. Ding \\ A. W. Roe \\ J. M. Kainerstorfer \\ L. Fu \\ S. Shoham \\ Editors
}

6-11 March 2021

Online Only, United States

Sponsored and Published by

SPIE 
The papers in this volume were part of the technical conference cited on the cover and title page. Papers were selected and subject to review by the editors and conference program committee. Some conference presentations may not be available for publication. Additional papers and presentation recordings may be available online in the SPIE Digital Library at SPIEDigitalLibrary.org.

The papers reflect the work and thoughts of the authors and are published herein as submitted. The publisher is not responsible for the validity of the information or for any outcomes resulting from reliance thereon.

Please use the following format to cite material from these proceedings:

Author(s), "Title of Paper," in Optical Techniques in Neurosurgery, Neurophotonics, and Optogenetics, edited by V. X. D. Yang, Q. M. Luo, S. K. Mohanty, J. Ding, A. W. Roe, J. M. Kainerstorfer, L. Fu, S. Shoham, Proc. of SPIE 11629, Seven-digit Article CID Number (DD/MM/YYYY); (DOI URL).

ISSN: 1605-7422

ISSN: 2410-9045 (electronic)

ISBN: 9781510640931

ISBN: 9781510640948 (electronic)

Published by

SPIE

P.O. Box 10, Bellingham, Washington 98227-0010 USA

Telephone +1 3606763290 (Pacific Time)

SPIE.org

Copyright (C) 2021 Society of Photo-Optical Instrumentation Engineers (SPIE).

Copying of material in this book for internal or personal use, or for the internal or personal use of specific clients, beyond the fair use provisions granted by the U.S. Copyright Law is authorized by SPIE subject to payment of fees. To obtain permission to use and share articles in this volume, visit Copyright Clearance Center at copyright.com. Other copying for republication, resale, advertising or promotion, or any form of systematic or multiple reproduction of any material in this book is prohibited except with permission in writing from the publisher.

Printed in the United States of America by Curran Associates, Inc., under license from SPIE.

Publication of record for individual papers is online in the SPIE Digital Library.

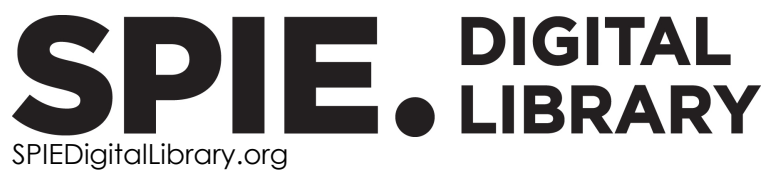

Paper Numbering: A unique citation identifier (CID) number is assigned to each article in the Proceedings of SPIE at the time of publication. Utilization of CIDs allows articles to be fully citable as soon as they are published online, and connects the same identifier to all online and print versions of the publication. SPIE uses a seven-digit CID article numbering system structured as follows:

- The first five digits correspond to the SPIE volume number.

- The last two digits indicate publication order within the volume using a Base 36 numbering system employing both numerals and letters. These two-number sets start with 00, 01, 02, 03, 04, $05,06,07,08,09,0 A, 0 B \ldots$... Z, followed by 10-1Z, 20-2Z, etc. The CID Number appears on each page of the manuscript. 


\section{Contents}

LASER SPECKLE AND OTHER OPTICAL METHODS

$116290 \mathrm{O}$ Cloud-based medical laser platform for phototherapy and treatment monitoring for glioblastoma [11629-5]

$11629 \mathrm{OH} \quad$ Multiphoton excitation of Rose Bengal to induce capillary photo-thrombosis [11629-6]

MICROSCOPY I

11629 OM Fast volumetric imaging of neural activity in deep brain [11629-24]

OPTICAL COHERECE TOMOGRAPHY AND DIFFUSE OPTICAL TOMOGRAPHY

11629 OV Noncontact optical assessment of spontaneous low-frequency fluctuations of cerebral blood flow in neonatal intraventricular hemorrhage [1 1629-9]

DIFFUSE CORRELATION SPECTROSCOPY

11629 1A Detection of cerebral blood flow and hemoglobin oxygenation using diffuse correlation spectroscopy and frequency-domain near-infrared spectroscopy during carotid endarterectomy [1 1629-14]

HUMAN BRAIN

$116291 \mathrm{~J} \quad$ Measuring myelin content and neuron density in the human brain with optical coherence tomography [11629-31]

AWAKE ANIMALS

$116291 \mathrm{M} \quad$ Imaging localized fast optical signals of neural activation with optical coherence tomography in awake mice [1 1629-34] 
$116291 Q \quad$ A 32-channel frequency-domain fNIRS system based on silicon photomultiplier receivers [11629-38]

11629 1T Diffusing wave spectroscopy: a unified treatment on temporal sampling and speckle ensemble methods [11629-41]

BRAIN ACTIVITIES

1162922 Vinculin tension probe in neurons [11629-50]

DISEASES

1162923 Blood-pressure-induced oscillations of cerebral hemodynamics during hemodialysis [1 1629-51]

NOVEL TECHNIQUES

$1162928 \quad$ Localization and imaging of white matter fiber crossings in whole mouse brains using diffusion MRI and serial blockface OCT [11629-56]

11629 2C Automated craniotomy with impedance-sensitive skull curvature profiling [11629-60]

\section{PHOTOACOUSTIC IMAGING}

$116292 \mathrm{E}$ Optoacoustic visualization of GCaMP6f labeled deep brain activity in a murine intracardiac perfusion model [11629-62]

$116292 \mathrm{~F} \quad$ Photoacoustic imaging of fear conditioning neuronal ensembles using a Fos-LacZ gene reporter system in the rat brain in vivo after intrathecal X-gal injection [1 1629-63]

JOINT SESSION: NIRS AND INNOVATIVE DIFFUSE OPTICS APPROACHES FOR CBF AND FUNCTIONAL IMAGING

$1162921 \quad$ Evaluation of neural information content from the phase component of a 32-channel frequency-domain fNIRS system [1 1629-66]

iv 


\section{POSTER SESSION}

$116292 \mathrm{~K}$ Internet of things-based functional near-infrared spectroscopy headband for mental workload assessment [11629-68]

$116292 \mathrm{~L} \quad$ A machine learning approach to classify working memory load from optical neuroimaging data [11629-69]

$116292 \mathrm{M} \quad \mathrm{K}$-means clustering for unsupervised participant grouping from fNIRS brain signal in working memory task [11629-70] 
Proc. of SPIE Vol. 11629 1162901-6

\section{Downloaded From: https://www.spiedigitallibrary.org/conference-proceedings-of-spie on 26 Apr 2023
Terms of Use: https://www.spiedigitallibrary.org/terms-of-use}

